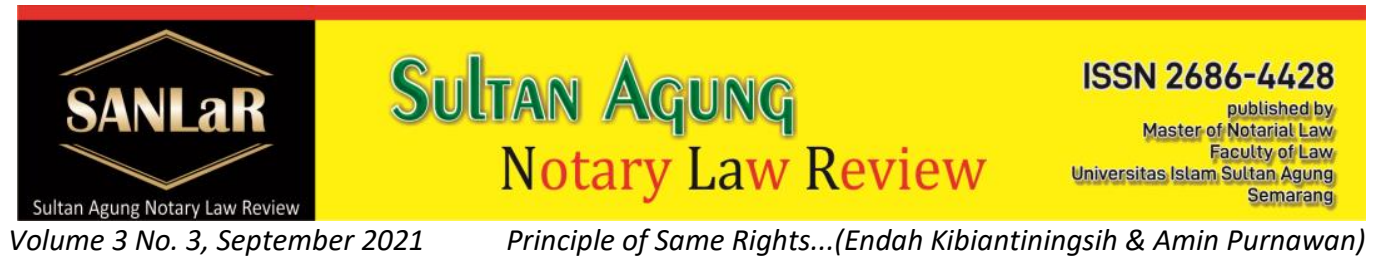

\title{
Principle of Same Rights to Land in Absentee Land Ownership
}

\author{
Endah Kibiantiningsih ${ }^{*}$ and Amin Purnawan ${ }^{* *}$ \\ ${ }^{*}$ Faculty of Law, Universitas Islam Sultan Agung (UNISSULA) Semarang, E-mail: \\ endahkb@gmail.com
}
${ }^{* *}$ Faculty of Law, Universitas Islam Sultan Agung (UNISSULA) Semarang, E-mail: amin.p@unissula.ac.id

\begin{abstract}
Land is one of the natural resources in Indonesia that can be used as a means to achieve the welfare of the nation's life, so it needs state intervention to regulate it. In accordance with the constitutional mandate as stated in Article 33 Paragraph (3) of the 1945 Constitution, Act No. 5 of 1960 concerning Basic Regulations on Agrarian Principles or called the UUPA is stipulated. All kinds of land rights can be granted to all Indonesian people, both men and women, regardless of race, ethnicity and religion. From these provisions, Article 10 of the UUPA paragraph (1) stipulates that every person and legal entity that a right to agricultural land is in principle has to work or actively cultivate it himself, by preventing extortion. The article does not explicitly explain that it is prohibited to own agricultural land in an absentee manner, but this article can be intended to do so. The term absentee land will not be found in statutory regulations, but it can be understood that absentee land is land ownership located outside the area where the owner lives. Agricultural land should actually be used and worked on in an effort to meet productivity which will increase the national economy. However, the prohibition on land ownership does not apply to Civil Servants (PNS) who are equal with those who are carrying out state duties. Based on the above background, the formulation of the problem that the author wants to put forward in this study are: (1) How is the application of the principle of equality of land rights in absentee land ownership at the Karanganyar Regency Land Office. (2) Is absentee land ownership at the Karanganyar Regency Land Office in accordance with the application of the principle of equal rights to land. (3) How to obtain rights to Absentee land at the Karanganyar Regency Land Office. This study uses a normative juridical method, namely research that is fundamental in certain methods, systematics and thoughts which aims to examine one or several legal phenomena by analyzing them. From the research in the field, it can be concluded that the prohibition of absentee land ownership in Karanganyar Regency is not in accordance with the principle of equal rights between civil servants and the general public. The way to register land ownership (in this case land with the term absentee) for civil servants, as well as in Karanganyar district is (1) Applying for a permit to the local BPN office (2) Identity Card and
\end{abstract}


appointment letter for PNS, TNI, POLRI (3) For retirees attach a statement letter that will manage the registered land itself. Ways to register land ownership for common citizens; (1) Identity Card, (2) Family Card, (3) Notice of Taxes Payable and (4) Land History.

Keywords : Equal; Rights; Principle; Absentee; Land.

\section{Introduction}

In the view of Islam, everything that is in the heavens and on earth, including the land, essentially belongs to Allah SWT alone. An-Nur: 24/42 which asserts that the ultimate owner of everything (including land) is Allah SWT alone. ${ }^{1}$ Then Allah SWT gives power (istikhlaf) to humans to manage according to His laws. Allah has determined that the land on earth is inherited to be used as property rights, as His word in QS al-Ahzab 33:27. ${ }^{2}$

In accordance with the constitutional mandate as stated in Article 33 Paragraph (3) of the 1945 Constitution, which determines:

"Earth, water and natural resources contained therein are controlled by the state and used for the greatest prosperity of the people".

Realization of Article 33 paragraph (3) of the 1945 Constitution then stipulated Act No. 5 of 1960 concerning Basic Regulations on Agrarian Principles or called UUPA.

Protection of agricultural land is further regulated in the UUPA Article 7, Article 10 paragraph (1), and Article 17 . The term absentee land will not be found in laws and regulations, but it can be understood that absentee land is land ownership located outside the area of residence the owner. ${ }^{3}$

Absentee ownership of agricultural land is expressly prohibited by the LoGA with the main provisions of land reform regulated in Articles 7, 10 and 17 of the LoGA and as its implementation, a Government Regulation in lieu of Act No. 56/PRP/1960 concerning Land Determination has been established and regulated more continued with the Regulation of the Minister of Agrarian and Spatial Planning / Head of the National Land Agency Number 18 of 2016 concerning Control of Agricultural Land Tenure, but in Karanganyar Regency land ownership on an absentee basis is still ongoing because Karanganyar Regency is one of the most fertile agricultural areas. Seeing this condition, many agricultural

\footnotetext{
${ }^{1}$ Al-Quran, Kementerian Agama RI, p. 695

${ }^{2}$ Ibid, p. 421

${ }^{3}$ Boedi Harsono. (2007)Menuju Penyempurnaan Hukum Tanah Nasional, Jakarta: Fakultas Hukum Universitas Trisakti, p. 385
} 
lands in Karanganyar Regency are in demand by entrepreneurs from outside, with the aim of being used as a means of investment. ${ }^{4}$

Agricultural land should actually be utilized and worked on in an effort to meet productivity which will increase the national economy. However, the prohibition on land ownership does not apply to Civil Servants/PNS. ${ }^{5}$

Based on the background above, the formulation of the problem that the author wants to put forward in this study are; How is the application of the principle of equality of land rights in absentee land ownership at the Karanganyar Regency Land Office, Is absentee land ownership at the Karanganyar Regency Land Office in accordance with the application of the principle of equal land rights and, How to obtain Absentee land rights at the Regency Land Office Karanganyar Regency.

\section{Research Methods}

This study uses a normative juridical method, its relationship with normative research, the approach used in legal writing according to Peter Mahmud Marzuki is as follows: ${ }^{6}$ case approach, statutory approach, historical approach, conceptual approach. The objectives of the research are to find out the application of the principle of equality of land rights in absentee land ownership at the Karanganyar Regency Land Office, to find out and analyze the suitability of the application of the principle of equal land rights to absentee land ownership at the Karanganyar Regency Office and, to determine the process of making Absentee Land Deeds at the Karanganyar Regency Land Office.

\section{Result and Discussion}

\subsection{Application of the principle of equal rights to land in absentee land ownership}

To measure the principle of equality of land rights in national land law between Civil Servants (PNS) and general citizens, in this study the researchers used the principle of land tenure rights as follows:

\footnotetext{
${ }^{4}$ Sigit Budi Prabowo, Pemilikan Tanah Pertanian Secara Absentee Dan Pertanggung Jawaban Hukum Badan Pertanahan Kabupaten Boalemo Atas Penerbitan Sertifikat (Studi Kasus di Kecamatan Paguyaman Kabupaten Boalemo). Jurnal Program Studi Magister Kenotariatan, Fakultas Hukum, Universitas Brawijaya, 2016.

${ }^{5}$ Chita Herdiyanti, (2017) Kepemilikan Tanah Absentee Oleh Pegawai Negeri Sipil Berdasarkan Peraturan Pemerintah Nomor 4 Tahun 1977, Acta Diurnal, Jurnal Hukum Kenotariatan dan kePPAT-an, ISSN: 2614-3542 EISSN: 2614-3550, Volume 1, Nomor 1, December 2017 ${ }^{6}$ Marzuki,Peter Mahmud. (2006). "Penelitian Hukum, Cetakan Kedua". Jakarta: Kencana Prenada Media Group, p. 93.
} 


\section{Nationality Principle}

This principle is reflected in Article 1 of the LoGA, which means that the earth, water and space within the territory of the Republic of Indonesia are the rights of the Indonesian people, so they are not solely the rights of their owners. Likewise, lands in the regions and islands are not solely the rights of the native people of the region or island in question.

In connection with the equality of land ownership rights for civil servants and general citizens both have rights that are equally obtained from this principle, or in other words the principle of nationality is a principle which states that only Indonesian citizens have property rights to land or are allowed to own land. Relationship with the earth and space by not discriminating between men and women as well as fellow citizens, both native and descendent.

\section{The Principle of the Right to Control the State}

This principleis stated in Article 2 of the LoGA. The meaning of the right to control the state is the state's demands on individuals, communities and the state itself to exercise rights in accordance with the obligations imposed on them in the form of utilizing land, protecting and guaranteeing the rights of other parties and preventing actions that cause other parties to lose opportunities or land rights. , with the aim of achieving the greatest prosperity of the people in the framework of a just and prosperous society. In connection with this research, the equality of land ownership rights granted by the state on the principle of state control rights between civil servants and general citizens have the same. In realizing this goal, the government issued a program called agrarian reform or what is now known as agrarian reform through the concept of land reform.

\section{The principle of recognition of customary rights.}

This principle is reflected in Article 3 of the UUPA Adi, so that customary land can be recognized and protected, the relevant customary law community must first be recognized and determined by the regent or mayor. Then, the administration of ulayat land can only be carried out, so that ulayat land can be registered in the land register.

\section{Principles of National Agrarian Law}

As stipulated in Article 5 of the UUPA which states that the agrarian law applicable to earth, water and space is customary law as long as it does not conflict with national and state interests. From this statement, civil servants and the general public in terms of land ownership have the same position, because both civil servants and the general public have the right to use the earth, water and space through local customary law. 


\section{Principles of Social Function}

As stated in Article 6 of the LoGA, the use of land must be adjusted to the circumstances and nature of the rights, so that it is beneficial for the welfare and happiness of the owner as well as for the community and the state. However, this provision does not mean that individual interests will be replaced by public (society) interests. In relation to the equality of land ownership rights between civil servants and general citizens there is no difference in cultivating land, both must be adjusted to the circumstances and nature of their rights.

\section{Land reform}

As stated in Articles 7, 10 and 17 of the LoGA. Land reform is an overhaul of land ownership and control and procurement. Basically, agricultural land refers to the purpose of land reform, which is carried out by local residents who are also the owners of the agricultural land. The land reform principle on the principle of land tenure rights for civil servants and the general public in relation to this research does not have equal rights. Because it is seen in accordance with one of the main points of land reform activities, there is an exception, namely the prohibition of absentee/guntai land ownership does not apply to civil servants.

7. The principle of equal rights to land for every Indonesian citizen, both male and female

In accordance with Article 9 paragraphs (1) and (2) property rights cannot be owned by foreign nationals and the transfer of property rights to foreign nationals is also prohibited. This shows that there is a right for anyone to acquire a land and to get the benefits and results. On this basis, the ownership and use of land rights for men and women are equal in the eyes of the law. Land rights are defined as rights that authorize the subject of the right to use the land in question. With this, civil servants and the general public have the same rights on the principle of equal rights to land for every Indonesian citizen, both male and female ${ }^{7}$.

\section{8. $\quad$ Land Use Principle}

As stipulated in Articles 13, 14 and 15 of the LoGA, land must be maintained according to the usual methods, in accordance with the instructions from the person concerned. The obligation to maintain this land is not only borne by the owner or the holder of the right in question, but also becomes the burden of

\footnotetext{
${ }^{7}$ Deen, Thaufiq., Ong Argo Victoria \& Sumain. (2018). Public Notary Services In Malaysia. JURNAL AKTA: Vol. 5, No. 4, 1017-1026. Retrieved from http://jurnal.unissula.ac.id/index.php/akta/article/view/4135
} 
every person, legal entity or agency that has a legal relationship with the land. Hereby, the provisions in Articles 13, 14 and 15 of the UUPA are mandatory for civil servants and general citizens.

\section{Land Registration Principle}

As stated in Article 19 of the LoGA. Land tenure rights on the principle of land registration in this study between civil servants and general citizens have different rights. This statement is based on the procedures and flow of land registration. Civil servants are given leeway and convenience in registering land, while general citizens go through a long and complicated process.

\subsection{Absentee Land Ownership Is In Accordance With The Application Of The Equality Of Land Rights Principle}

From the sub-chapter above, it can be concluded that absentee land ownership is not in accordance with the application of the principle of equal rights to land. Although of the 9 principles that the researcher uses, only 2 principles show that there is no equal rights between civil servants and the general public.

One example of a case that shows that there is no equality of rights between civil servants and the general public is found in the case of absentee land purchases being reversed by the buyer's wife to get the land, because the wife of the buyer is a civil servant. Mr. B bought a plot of land with an area of 2,500 $\mathrm{m} 2$ in the Jumantono area of Karanganyar. It turns out that the land purchased by Mr. B is agricultural land, where in the provisions relating to the purchase of agricultural land, the buyer must be domiciled in one sub-district, while Mr. B has his address at Sedahromo, Kartasura District, Sukoharjo Regency. However, Mr. B has a wife, namely Mrs. $C$ who is a civil servant, where the provisions for the purchase of agricultural land do not apply to those who are Civil Servants, TNI and POLRI.

In this case Mr. B has the advantage of getting the land by taking advantage of his wife's status as a civil servant, even though in the end the land will be removed from agricultural land to become a warehouse.

In connection with the above case, it is certain to deviate from the objectives of land reform, namely, firstly, to organize a just and prosperous society, especially to improve the standard of living of the farmers. Second, is to strengthen and expand land ownership for all Indonesian people, especially farmers. ${ }^{8}$

This case is also not in line with the land reform principle of Article 10 of the LoGA, namely the principle of the obligation to work or actively cultivate their own land.

Another case was found that Mrs. $Y$ had an inheritance of agricultural land in Colomadu, while Mrs. Y lived with her husband in Wonogiri Regency. Legally,

${ }^{8}$ Boedi Harsono, op.cit., p. 350 
mother Y's land can be owned by means of Mrs. Y's having to change domicile in Colomadu or the rights to the absentee land in question must be transferred to someone else, even though the inheritance is agricultural land, it can also be said that the land is absentee land.

Article 3 paragraph (1) Government Regulation Number 224 of 1961 which stipulates that anyone who has land rights located outside the sub-district where the owner resides must sell, grant or transfer ownership of the land rights within 6 months. The provisions in Article 10 paragraph (1) explain that "all persons and legal entities are prohibited from having land rights outside the sub-district where they live", this means that everyone must transfer their land rights to other people who live in the same sub-district where the land is located, but this article is no longer relevant to the current condition of society, because nowadays the distance between cities is even closer because of the easy means of transportation.

In absentee land registration from inheritance must go through a complicated process, by attaching land history, namely proof of land ownership, because this is inherited land, there must be an inheritance letter or inheritance distribution for all family members.

\subsection{How to Get Absentee Land in Karanganyar Regency}

The provisions governing Absentee/guntai land can be found in Article 10 of the LoGA, PP No. 41 of 1964, PP No. 4 of 1977, and the Minister of Home Affairs Regulation No. 15 of 1974. Absentee/guntai land can occur due to 2 (two) things, namely:

a. If an owner of agricultural land leaves the sub-district where he lives where his agricultural land is located.

b. If the owner of the agricultural land dies, while the heirs are domiciled in another sub-district.

c. As for The method of obtaining absentee land for civil servants and the general public is as follows:

\section{How to Get Absentee Land for Civil Servants}

Exceptions for retired civil servants are regulated in Government Regulation no. 4 of 1977, namely Article 2, which stipulates that the exception of land ownership on an absentee basis also applies to retired Civil Servants and widows of Civil Servants as well as widows of retired Civil Servants as long as they are not remarried. Civil servants and military officials as well as those who are equal can own land on an absentee basis, limited to $2 / 5$ of the maximum area determined for the area concerned. The ownership may be continued after retirement, if later he changes his residence to the sub-district where the land is concerned, the ownership can automatically be increased up to the maximum limit. 
The purpose of holding an exception for absentee land ownership is to protect the rights of those who are carrying out tasks assigned by the state and religion which cause them to be unable to actively seek and work on their own agricultural land rights. Meanwhile, for Civil Servants who are 2 years before retirement are allowed to own agricultural land on an absentee basis, it is intended that the Civil Servant after he retires still has a source of income that can be used for his livelihood and that of his family. It is also based on the consideration that if a retired civil servant is not young anymore, it is difficult to apply for a job.

In addition, it is also a form of appreciation for civil servants because they can be said to be servants of the state. While the purpose of giving an exception for a civil servant widow to own agricultural land in absentee is because the widow is considered after the death of her husband, she has no one to provide a living so that she is allowed to own agricultural land in absentee which she can use to support her life and her family.

The way to register land ownership (in this case land with the term absentee) for PNS, TNI, POLRI as well as those who are equated with those who are carrying out State duties are as follows;

a. Apply for a permit to the local BPN office

b. Attach a National Identity Card (KTP) and a letter of appointment for PNS, TNI, POLRI

C. For retirees, attach a statement that they will manage the registered land themselves.

\section{How to get absentee land for General Citizens}

In this case, the general public can also own absentee land with the provision that the land owner resides in the sub-district bordering the sub-district where the land is located, provided that the distance between the owner's residence and the land is still possible to work on the land efficiently.

Based on information from one of the employees of the Karanganyar Regency Land Office, Mr. Wasina,. SH there is no absentee land in Karanganyar Regency. Ministerial Regulation No. 16 of 2018 who can own agricultural land and where to live. Mr. Wasina stated that the land registered by the applicant who lives far away from his/her own land cannot be considered as absentee land. In this day and age, the vehicle is easy to reach, even though the owner is domiciled outside the sub-district, it can still be easily reached for agricultural land to be cultivated. It is also not explained how far the distance between the domicile of the land and the land to be purchased for the border area is, so according to Wasina the land will still be effective and efficient. But the rules are like that, so the land office still follows the Regulation No. 16 of $2018 .^{9}$

${ }^{9}$ Interview with Mr Wasina, SH as the head of the Karanganyar BPN office 
Ways to register land ownership (in this case land with the term absentee) for general citizens;

a. Identity Card (KTP),

b. Family Card (KK),

c. Notice of Taxes Payable (SPPT),

d. Land history, namely proof of land ownership, for example inherited land, there must be a letter of inheritance or distribution of inheritance for all family members. In the history of land, it is complicated because if the land is inherited, then all the parties concerned must gather for signatures and ask for the approval of all family members. That way it takes a long time to determine the time so that all requirements are met, certificate creation will be completed quickly depending on whether or not the requirements have been fulfilled.

\section{Closing}

There is a principle of equality of land rights in the national land law between Civil Servants (PNS) and general citizens, from this research obtained several principles of equal tenure rights over land as follows: a) The principle of nationality is provided for in Act No. 5 of 1960 Article 1 Equality of rights of civil servants with general citizens is the same. b) The principle of the right to control the state is stipulated in Act No. 5 of 1960 Article 2, the equal rights of civil servants and general citizens are the same. c) The principle of acknowledgment of customary rights in Act No. 5 of 1960 Article 3 equal rights of civil servants and general citizens. d) The principle of ulayat national agrarian law as stipulated in Act No. 5 of 1960 Article 5 equal rights of civil servants with ordinary citizens. e) The principle of social function as stipulated in Act No. 5 of 1960 Article 6 equal rights of civil servants and general citizens. f) The principle of land reform, as stipulated in Act No. 5 of 1960 Articles 7, 10 and 17, equal rights of civil servants and general citizens are not the same. g) The principle of Equality of land rights as stipulated in Act No. 5 of 1960 Article 9 equal rights of civil servants with general citizens. h) The principle of land use is stipulated in Act No. 5 of 1960 Articles 13,14, 15, equal rights of civil servants and general citizens. i) The principle of land registration as stipulated in Act No. 5 of 1960 Article 19 equal rights of civil servants with ordinary citizens is not the same. From the research in the field, it can be concluded that the prohibition of absentee ownership of land is enforced Karanganyar Regency is not in accordance with the principle of equal rights between civil servants and the general public.

\section{References}

\section{Al-Quran}

Journals: 
[1] Deen, Thaufiq., Ong Argo Victoria \& Sumain. (2018). Public Notary Services In Malaysia. JURNAL AKTA: Vol. 5, No. 4, 1017-1026. Retrieved from http://jurnal.unissula.ac.id/index.php/akta/article/view/4135

[2] Harsono, Boedi, (2007), Menuju Penyempurnaan Hukum Tanah Nasional, Jakarta: Fakultas Hukum Universitas Trisakti

[3] Herdiyanti, Chita, (2017) "Kepemilikan Tanah Absentee Oleh Pegawai Negeri Sipil Berdasarkan Peraturan Pemerintah Nomor 4 Tahun 1977", Acta Diurnal, Jurnal Hukum Kenotariatan dan ke-PPAT-an, ISSN: 26143542 EISSN: 2614-3550, Volume 1, Nomor 1, December 2017

[4] Prabowo, Sigit Budi, (2016). "Pemilikan Tanah Pertanian Secara Absentee Dan Pertanggung Jawaban Hukum Badan Pertanahan Kabupaten Boalemo Atas Penerbitan Sertifikat (Studi Kasus di Kecamatan Paguyaman Kabupaten Boalemo)". Jurnal Program Studi Magister Kenotariatan, Fakultas Hukum, Universitas Brawijaya.

Book:

Peter Mahmud,Marzuki, (2006).“Penelitian Hukum, Second Edition”. Jakarta: Kencana Prenada Media Group

Regulation:

[1] Act No. 5 of 1960 concerning Basic Regulations on Agrarian Principles or called the LoGA.

[2] Constitutional Mandate of the 1945 Constitution Article 33 Paragraph (3).

[3] Government Regulation Article 3 paragraph (1) Number 224 of 1961

[4] Government Regulation in lieu of Act No. 56/PRP/1960 concerning Land Determination.

Interview:

Interview with Mr Wasina,. SH as the head of the Karanganyar BPN office 